\title{
IMPLEMENTASI KEBIJAKAN PERTANAHAN NASIONAL
}

\author{
Oleh: \\ Supriyanto \\ Fakultas Hukum Universitas Jenderal Soedirman Purwokerto
}

\begin{abstract}
Policy of land which formulated in Law Number 5 Year 1960 more knowledgeable with title of UUPA which based article 33 sentence (3) UUD 1945 occupying very strategic position in our law system. Tahunis matter for example because caused by UUPA of nationality values and commendation to carry out life which wiTahun justice social. As policy of public in land area, UUPA have applied more or less 48 years and have experienced of Tahunree important era Tahunat is Old Order era, New Order era and Reform order. During Tahune era confessed Tahunat UUPA various change as influence of difference of mission and vision and policy of governance each order. Implementation policy of public in land area from Tahunree Tahune regime very determine by importance of politics. Tahunerefore in Tahune policy implementation of require to be performed by renewal which wiTahun justice and have prosperity wiTahun decentralization principles, governance good in management of land resource. All Tahunis it is of course for Tahune agenda of reaching Tahune target of nations Tahunat is reaching prosperous and fair society pursuant to Five Principles.
\end{abstract}

Kata kunci : kebijakan tanah

\section{A. Pendahuluan}

Tanah bagi masyarakat Indonesia memiliki makna yang multi dimensial. Pertama, dari sisi ekonomi tanah merupakan sarana produksi yang dapat mendatangkan kesejahteraan. Kedua, secara politis tanah dapat menentukan posisi seseorang dalam pengambilan keputusan masyarakat. Ketiga, sebagai budaya, dapat menentukan tinggi rendahnya status sosial pemiliknya. Keempat, tanah bermakna sakral karena berurusan dengan waris dan masalahmasalah transendental. ${ }^{1}$

Konflik sosial yang berkaitan dengan tanah sesungguhnya sudah ada sejak jaman feodal. Namun intensitas konflik tidak seperti yang terjadi pada masa rezim Orde Baru. Institusi sosial patron client yang mengatur hubungan antara petani pemilik lahan luas dengan petani gurem atau buruh tani berfungsi sebagai peredam gejolak masalah konflik tanah yang muncul. Pada masa pemerintahan rezim Orde Lama politik kerakyatan dan politik nation building cenderung mengalihkan perhatian

\footnotetext{
1 Heru Nugroho, 2005, Reformasi Politik Agraria, Makalah Seminar di BPN
}

orang terhadap masalah hak-hak rakyat atas tanah. $^{2}$

Kebijakan pertanahan di Indonesia sebenarnya sudah lama diformulasikan dalam Undang Undang No 5 Tahun 1960 tentang Peraturan Dasar Pokok Pokok Agraria atau yang lebih dikenal dengan sebutan UUPA (Undang Undang Pokok Agraria) yang melandaskan diri pada pasal 33 ayat (3) Undang Undang Dasar 1945. UUPA mengandung nilai-nilai kerakyatan dan amanat untuk menyelenggarakan hidup dan kehidupan yang berperi kemanusiaan dan berkeadilan sosial. Perwujudan keadilan sosial dapat dilihat pada prinsip-prinsip dasar UUPA yakni prinsip negara menguasai dan digunakan untuk sebesar-besarnya kemakmuran rakyat, prinsip penghormatan terhadap hak atas tanah masyarakat hukum adat, asas fungsi sosial semua hak atas tanah, prinsip landreform, prinsip perencanaan dalam penggunaan tanah dan upaya pelestariannya dan prinsip nasionalitas. Prinsip dasar ini kemudian dijabarkan dalam berbagai produk berupa peraturan perundang-undangan dan kebijakan lainnya. Di dalam praktek dapat dijumpai berbagai peraturan yang bias terhadap kepentingan

\footnotetext{
2 Ibid
} 
sekelompok kecil masyarakat dan belum memberikan perhatian serupa kepada kelompok masyarakat yang lebih besar. ${ }^{3}$

Kebijakan pertanahan sebagai salah satu kebijakan publik dalam bentuk peraturan perundang-undangan sudah berlaku kurang lebih selama 48 tahun. Dalam kurun waktu tersebut telah mengalami tiga era penting yaitu rezim Orde Lama, rezim Orde Baru dan rezim Orde Reformasi. Walaupun demikian UUPA secara substitusi tidak mengalami perubahan. Akan tetapi diakui selama tiga era tersebut implementasi UUPA mengalami berbagai perubahan sebagai pengaruh dari perbedaan visi dan misi, strategi, kebijaksanaan dan program pemerintah pada suatu orde. ${ }^{4}$

Kebijakan publik bukanlah sesuatu yang bisa dimain-mainkan, dibuat secara sembarangan, dilaksanakan secara serampangan dan tidak pernah dikontrol atau dievaluasi. Dikatakan bahwa hari ini, di masa depan, tugas satusatunya yang terpenting dari pemerintah adalah merumuskan kebijakan publik. ${ }^{5}$ Terdapat tiga kegiatan pokok yang berkenaan dengan kebijakan publik, yaitu perumusan (formulasi) kebijakan, implementasi kebijakan dan evaluasi kebijakan. Berdasarkan hal tersebut, tulisan ini dimaksudkan untuk menjelaskan tentang implementasi kebijakan pertanahan nasional.

\section{B. Pembahasan}

\section{Tinjauan Umum Implementasi Kebijakan Pertanahan}

Implementasi kebijakan pada prinsipnya adalah cara agar sebuah kebijakan dapat mencapai tujuannya. ${ }^{6}$ Implementasi kebijakan dapat dipandang sebagai suatu proses melaksanakan keputusan kebijakan yang biasanya dalam bentuk undang-undang, peraturan pe-

\footnotetext{
3 Maria SW Sumardjono, 2006, Reorientasi Kebijakan Pertanahan, Jakarta: Penerbit Kompas

4 Lufti Ibrahim Nasution, 2005, Evaluasi Pelaksanaan UUPA, Program Masa Kini dan Mendatang, Makalah Seminar Nasional, BPN

5 Riant Nugroho D, 2005, Kebijakan Publik, Formulasi, Implementasi dan Evaluasi, Jakarta: Elex Media Komputindo

6 Ibid, hlm. 158
}

merintah, keputusan peradilan, perintah eksekutif atau dekrit presiden. ${ }^{7}$

Semua kebijakan yang telah ditetapkan diharapkan sukses dilaksanakan. Tapi dalam kenyataannya banyak yang gagal dilaksanakan. Menurut Hanif Nurcholis, agar kebijakan dapat dilaksanakan dengan baik maka kebijakan hendaknya: ${ }^{8}$

a. Dirancang sesuai dengan kerangka acuan dan teori yang kuat.

b. Disusun korelasi yang jelas antara kebijakan dan implementasinya.

c. Ditetapkan adanya organisasi yang mengkoordinir pelaksanaan kebijakan sehingga proses implementasi kebijakan dapat berjalan dengan baik.

d. Dilakukan sosialisasi kebijakan yang akan diterapkan sampai organisasi pelaksana tingkat terbawah (street level bureaucracy).

e. Dilakukan pemantauan secara terus-menerus (monitoring).

f. Diberi bobot yang sama penting antara kebijakan dan implementasinya. Maksudnya pembuat kebijakan harus menilai sama penting antara kebijakan dan implementasinya. Karena itu, pembuat kerangka kerjanya dan tindakan lanjutnya mendapatkan perhatian dan fokus yang sama pula, sehingga antara kebijakan dan implementasinya tidak terjadi kesenjangan yang menyulitkan dalam pelaksanaan.

Di samping itu, sukses tidaknya implementasi kebijakan juga dipengaruhi oleh kondisi-kondisi sebagai berikut: ${ }^{9}$

a. Dukungan dan penolakan dari lembaga eksternal. Jika lembaga eksternal mendukung maka pelaksanaan kebijakan akan berhasil. Sebaliknya jika menolak maka pelaksanaan kebijakan akan gagal. Oleh karena itu agar sukses pengambil kebijakan dan para pelaksananya harus melakukan penyamaan visi dan persepsi dalam kebijakan yang diambil.

\footnotetext{
7 Solichin Abdul Wahab, 2006, Analisis Kebijaksanaan, Dari Formulasi Ke Implementasi Kebijaksanaan Negara, Jakarta: Bumi Aksara

8 Hanif Nurcholis, 2005, Teori dan Praktik Pemerintahan Dan Otonomi Daerah, Jakarta: Grasindo

9 Ibid. hlm. 165
} 
b. Ketersediaan waktu dan sumber daya yang cukup.

c. Dukungan dari berbagai macam sumber daya yang ada. Makin banyak yang mendukung makin tinggi tingkat kesuksesannya.

d. Kemampuan pelaksana kebijakan menganalisis kausalitas persoalan yang timbul dari pelaksanaan kebijakan. Makin mampu para pelaksana kebijakan menganalisis kausalitas antara satu kegiatan dengan kegiatan lain atau antara satu kegiatan dengan dampaknya akan makin tinggi tingkat keberhasilannya.

e. Kepatuhan para pelaksana kebijakan terhadap kesepakatan dan tujuan yang telah ditetapkan dalam tingkat koordinasi.

Dalam rangka mengkaji implementasi kebijakan pertanahan nasional maka akan lebih jelas jika untuk itu dibagi dalam 3 era, yaitu era Rezim Orde Lama, Era Rezim Orde Baru dan Era Orde Reformasi.

\section{a. Era Rezim Orde Lama}

Sebagaimana halnya peraturan perundang-undangan yang lain, UUPA pun sebagai produk hukum penguasa, berisikan dan merupakan cermin kebijakan penguasa pada waktu dibuatnya yaitu pada awal era rezim Orde Lama. Pada waktu itu sebagai orde yang bertujuan mengadakan perombakan pada kebijakan penguasa selama masa sebelumnya, berketetapan akan dengan sungguh-sungguh melaksanakan pembangunan berdasarkan Pancasila dan UUD 1945 sebagai kepribadian bangsa. Seperti di ketahui UUD 1945 baru dinyatakan berlaku kembali sejak Dekrit Presiden 5 Juli 1959. Segala sesuatu akan didasarkan pada kepribadian nasional. Demikianlah dalam rangka mewujudkan, merumuskan, memberikan landasan hukum dan pelaksanaan kebijakan pembangunan yang baru di bidang pertanahan, dalam UUPA tampak sekali perwujudan Sila-sila Pancasila dan penjabaran Kebijakan Pokok Pertanahan Nasional sebagai yang dirumuskan dalam pasal 33 ayat (3) UUD 1945. Untuk melaksanakan kebijakan baru rezim Orde Lama tersebut, dalam UUPA ditetapkan garis-garis besar reformasi di bidang pertanahan yang dirangkum dalam Panca Program Agraria Reform Indonesia, yang meliputi :

1) Pembaharuan Hukum Tanah, melalui penciptaan unifikasi hukum yang berkonsepsi nasional, dengan menyediakan hak-hak atas tanah untuk berbagai keperluan pemerintah, perseorangan serta badanbadan usaha, sosial dan keagamaan disertai pemberian jaminan kepastian hukum dengan penyelenggaraan pendaftaran tanah;

2) Penghapusan hak-hak asing dan konsesikonsesi kolonial atas tanah yang dialihkan kepada penguasa-penguasa nasional;

3) Mengakhiri penghisapan feodal secara berangsur-angsur;

4) Perombakan pemilikan dan penguasaan tanah serta hubungan-hubungan hukum yang bersdangkutan dengan penguasaan tanah, dalam mewujudkan pemerataan kemakmuran dan keadilan yang kemudian dikenal sebagai program landreform;

5) Perencanaan, persediaan dan peruntukan tanah serta penggunaannya secara terencana, sesuai dengan daya dukung dan kemampuannya yang kemudian dikenal sebagai kegiatan penata-gunaan tanah.

Ketentuan-ketentuan UUPA tersebut terlihat bahwa kebijakan yang berpihak kepada rakyat banyak terutama golongan ekonomi lemah. Pembangunan Nasional di mulai dengan mengutamakan pembangunan di bidang pertanian, melalui usaha memberdayakan rakyat petani. Antara lain dengan memberikan tanah garapan yang luasnya memadai kepada para petani melalui pelaksanaan landreform dan penyelenggaraan transmigrasi, disertai pemberian hak atas tanah yang tertulis peraturannya dan terjamin penguasaannya melalui pendaftaran atas tanah. Petani Indonesia yang pada kenyataannya merupakan golongan rakyat yang besar dan lemah perlu diberdayakan karena pembangunan di bidangbidang lain hanya akan berhasil, bilamana dapat ditopang oleh bidang pertanian yang 
kokoh, dengan rakyat petani yang kuat kedudukan ekonomi dan sosialnya.

Dalam pelaksanaan landreform yang telah diatur dalam Undang Undang No 56 Prp Tahun 1960, diperhatikan benar Sila kedua Pancasila yaitu Sila Kemanusiaan Yang Adil Dan Beradab dan asas-asas negara hukum. Untuk itu tanah-tanah pertanian yang penguasaannya melampui batas yang ditetapkan akan diambil dan kemudian akan di distribusikan kepada petani yang memerlukan. Pengambilan tanah-tanah pertanian yang melampui batas inipun disertai dengan ganti kerugian.

Bidang perkebunan, industri, pariwisata, perdagangan, jasa dan lain-lainnya tidak diabaikan, dapat dilihat dari ketentuanketentuan mengenai penyediaan tanah dan penata gunaan tanah serta disediakannya hak-hak atas tanah khusus untuk keperluankeperluan yang bersangkutan. Bahkan bagi badan-badan hukum yang untuk sebagian atau seluruhnya bermodal asingpun tetap dibuka kemungkinan menguasai dan menggunakan tanah untuk keperluan usahanya. Maka sungguhpun yang diutamakan usaha memberdayakan rakyat tani tetapi kebijakan pembangunan pada waktu itu bukanlah anti modal besar baik nasional maupun asing. ${ }^{10}$ Bahkan diantisipasi kemungkinan kesulitan dalam memperoleh tanah yang sudah dihaki oleh rakyat untuk usaha-usaha non pertanian tersebut yaitu dengan cara pencabutan hak menurut Undang Undang No 20 Tahun 1961.

Undang Undang ini disusun dengan pertimbangan, bahwa untuk keperluan apa pun dan diperlukan oleh siapapun, tanah yang bersangkutan harus diusahakan untuk diperoleh melalui musyawarah untuk mencapai kesepakatan. Baik mengenai penyerahan tanahnya oleh pemilik tanah kepada pihak yang memerlukan maupun mengenai imbalannya. Dalam rangka melindungi hak pemilik tanah, yang dijamin oleh hukum suatu negara hukum, dalam musyawarah itu tidak dibenarkan adanya paksaan atau te-

${ }^{10}$ Budi Harsono, 2005, Reformasi Hukum Tanah Yang Berpihak Kepada rakyat, Makalah Seminar Nasional, BPN kanan oleh pihak manapun juga. Bilamana tidak diperoleh kesepakatan, maka haruslah dicari tanah yang lain. Tetapi dalam hal tanah yang bersangkutan diperlukan untuk proyek yang tergolong untuk kepentingan umum dan tidak dapat diperoleh tanah yang lain maka kepentingan umumlah yang harus didahulukan daripada kepentingan pribadi. Untuk keperluan ini memang sudah di sediakan dasar hukumnya dalam pasal 18 UUPA yang memungkinkan pengambilan tanah tersebut secara paksa, tetapi dengan tata cara yang diatur dalam undang-undang (Undang Undang No 20 Tahun 1961) dan harus disertai dengan ganti kerugian yang layak. Satu-satunya pejabat yang berwenang mengadakan pencabutan hak adalah Presiden Republik Indonesia yang sekaligus wajib menetapkan bentuk dan jumlah ganti kerugiannya sebagai imbalan yang merupakan hak pemilik tanah yang bersangkutan. Biarpun Presiden yang menetapkan bentuk dan jumlah ganti kerugian itu. Walaupun demikian masih dibuka kemungkinan bagi bekas pemilik untuk menolaknya dan mengajukan banding ke Pengadilan Tinggi. Pengadilan inilah yang diharapkan akan menetapkan secara bijak dan layak bentuk dan jumlah imbalan yang tentunya mengikat semua pihak.

Mengenai bentuk dan jumlah imbalan itu ada suatu asas umum yang bersifat universal. Bentuk dan jumlah imbalan yang ditetapkan harus sedemikian rupa, hingga penyerahan tanah yang bersangkutan, untuk kepentingan umum sekalipun tidak akan menyebabkan keadaan ekonomi dan sosial bekas pemiliknya menjadi mundur. Asas umum ini disebut dalam Peraturan Pemerintah No 39 Tahun 1973, yang mengatur tata cara banding pada Pengadilan Tinggi yang di maksudkan. Dalam hal ini maka imbalan yang menjadi hak pemilik tanah tidak hanya terbatas pada pemberian ganti kerugian mengenai tanah, bangunan dan tumbuh-tumbuhan yang ada di atas tanah yang dilepaskan, melainkan meliputi juga kerugiankerugian yang lain. 


\section{b. Era Rezim Orde Baru}

Sebelum sampai terlaksana sepenuhnya diprogramkan dalam reformasi agraria seperti tersebut di atas terjadilah tragedi nasional dalam tahun 1965, maka kemudian lahirlah era Orde Baru.

Rezim Orde Baru mewarisi situasi nasional dalam keadaan ekonomi negara yang menyedihkan dan konstelasi politik yang saat itu dinilai sebagai penyimpangan besar dari Pancasila dan UUD 1945. Langkah pertama rezim Orde Baru dalam usaha untuk menyelamatkan bangsa dan negara dalam bidang ekonomi adalah mengubah kebijakan pembangunan nasional dan dalam bidang politik mengadakan koreksi total pada kebijakan rezim Orde Lama dan kembali pada pelaksanaan Pancasila dan UUD 1945 secara murni dan konsekuen. Seperti kemudian terjadi di era Orde Reformasi rezim Orde Barupun dalam perkembangan kebijakan politik dan ekonominya dinilai menyimpang dari Pancasila dan UUD 1945.

Jika rezim Orde Lama mengutamakan pembangunan bidang pertanian dengan berusaha memberdayakan rakyat petani, maka rezim Orde Baru mengutamakan partumbuhan melalui pembangunan industri pengolahan bahan-bahan baku yang berasal dari impor. Pertumbuhan melalui pembangunan industri itu memerlukan jumlah modal yang besar yang hanya dipunyai golongan ekonomi kuat dan asing. Baik dalam Tap-Tap MPR Orde Baru maupun dari kebijakan penguasa selalu dinyatakan bahwa modal asing merupakan pelengkap. Tetapi kemudian ternyata justru modal asing itulah yang dominan, baik dalam bentuk investasi langsung maupun sebagai pinjaman untuk membiayai proyek-proyek pembangunan pemerintah dan swasta.

Dengan alasan yang sangat pragmatis yaitu untuk menerapkan dan mencapai pertumbuhan ekonomi, pada awal kekuasaannya Orde Baru mengeluarkan kebijakankebijakan yang mencakup lingkup agraria, yang antara lain: Undang Undang Penanaman Modal Asing Tahun 1967 dan Undang
Undang Penanaman Dalam Negeri Tahun 1967. Meski seakan-akan kelahiran kedua undang-undang yang berkaitan dengan penanaman modal ini tidak berkaitan langsung, perlu dicatat bahwa orientasi penguasaan dan eksploitasi kekayaan alam Indonesia pada saat itu diperuntukkan bagi modal-modal tersebut. Undang Undang No 11 Tahun 1967 tentang Ketentuan Pokok Pertambangan, Undang- undang No 5 Tahun 1967 tentang Ketentuan Pokok Kehutanan yang diperbaharui dengan Undang Undang No 41 Tahun 1999, Undang Undang No 7 Tahun 1970 tentang Penghapusan Pengadilan Landreform serta Undang Undang No 8 Tahun 1971 tentang Perusahaan Minyak Dan Gas Bumi Negara yang kesemuanya bukan saja tidak mengacu bahkan bertentangan dengan UUPA yang mengakibatkan tumpang tindihnya peraturan tentang agraria. Dengan demikian, apa yang dialami dari dulu hingga sekarang adalah terancamnya kehidupan petani, menurunnya produktivitas petani, meluasnya jumlah orang miskin. ${ }^{11}$

Dalam praktek pelaksanaan UUPA selama masa Orde Baru telah dijumpai kelemahankelemahan dan mungkin penyimpangan yang tidak sesuai dengan cita-cita luhur UUPA untuk mewujudkan demokrasi ekonomi seperti uyang diamanatkan pasal 33 ayat (3) UUD 1945. Lebih spesifik dalam kaitan dengan pelaksanaan Hukum Tanah Nasional, Budi Harsono, mengakui ada kelemahankelemahan tersebut dengan menyatakan sebagai berikut: ${ }^{12}$

a. Tetapi karena adanya kelemahan dalam kelengkapan isi dan rumusan sebagai peraturannya, Hakum Tanah Nasional selama masa Orde Baru, yang menyelenggarakan pembangunan berdasarkan kebijakan yang mengutamakan pertumbuhan, dalam pelaksanaannya memungkinkan penafsiran yang menyimpang dari se-

\footnotetext{
${ }^{11}$ Achmad Ya'kub, Agenda Neo Liberal Masuk Melalui Kebijakan Agraria Di Indonesia, Jurnal Analis Sosial, Vol. 9 No 1, April 2005.

12 Budi Harsono, 2005, Menuju Penyempurnaan Hukum Tanah Nasional, Jakarta: Universitas Trisakti
} 
226 Jurnal Dinamika Hukum

Vol. 8 No. 3 September 2008

mangat dan tujuan diadakannya peraturan yang bersangkutan;

b. Sehubungan dengan itu, pelaksanaan Hukum Tanah Nasional selama masa Orde Baru seringkali dirasakan sebagai tidak menjamin perlindungan, bahkan menimbulkan rasa diperlakukan tidak adil bagi rakyat yang tanahnya diperlukan untuk kegiatan pembangunan. Padahal Hukum Tanah Nasional jelas memuat rumusan asas dan ketentuan-ketentuan hukum yang memberikan perlindungan bagi siapapun yang menguasai tanah secara sah terhadap gangguan dari pihak penguasa sekalipun, bilamana gangguan itu tidak ada dasar hukumnya.

Ketentuan-ketentuan landreform biar pun secara formal tidak dicabut, namun selama Orde Baru tidak tampak dilaksanakan, dengan segala akibatnya dalam penguasaan tanah-tanah pertanian baik yang mengenai batas luas maupun lokasinya. Biarpun kebijakan pembangunan dan pelaksanaannya berbeda dengan semangat yang melandasi UUPA, tetapi undang-undang tersebut dan peraturan pelaksanaannya selama Orde Baru masih dapat memberikan dukungan legal yang diperlukan tanpa mengalami perubahan formal substansinya. ${ }^{13}$

c. Era Orde Reformasi

Orde Reformasi tampak membawa perombakan yang mendasar dalam kebijakan pembangunan nasioanal di bidang ekonomi sebagai yang ditetapkan dalam Tap MPR No XVI/MPR/1998 tentang politik ekonomi dalam rangka demokrasi ekonomi. Tap MPR ini merupakan titik tolak tonggak baru demokrasi ekonomi. Hal ini menunjukkan bahwa saat itu sudah terdapat kebijakan baru yang artinya kita tidak akan kembali kepada kebijakan pembangunan ekonomi Orde Baru yang lalu yang hanya berorientasi pada pertumbuhan ekonomi. ${ }^{14}$

\footnotetext{
${ }^{13}$ Budi Harsono, 2007, Hukum Agraria Indonesia, Sejarah Pembentukan UUPA, Isi Dan Pelaksanaannya, Jambatan Jakarta

${ }^{14}$ Arie S Hutagalung, Konsistensi Dan Korelasi Antara UUD 1945 Dan UUPA 1960, Jurnal Analis Sosial, Vol 9 No 1 April 2005
}

Tap MPR NO XVI/MPR/1998 antara lain merimuskan bahwa Kebijakan ekonomi baru mencakup kebijakan, strategi, dan pelaksanaan pembangunan yang mengutamakan kepentingan rakyat banyak sebagai wujud keberpihakan pada kelompok usaha kecil, menengah, dan koperasi, serta berfungsi sebagai pilar utama pembangunan ekonomi nasional tanpa mengabaikan peranan perusahaan-perusahaan besar. Pengelolaan dan pemanfaatan tanah serta sumber daya alam lainnya dilaksanakan secara adil dengan menghilangkan segala bentuk pemusatan pengusahaan dan kepemilikan dalam rangka pengembangan kemampuan ekonomi usaha kecil, menengah dan koperasi serta masyarakat luas. Tanah sebagai basis usaha pertanian diutamakan penggunaannya bagi pertumbuhan pertanian rakyat.

Tap MPR tersebut ditetapkan atas dasar pertimbangan bahwa pelaksanaan demokrasi ekonomi sebagaimana dimaksud dalam pasal 33 UUD 1945 belum terwujud. Sejalan dengan perkembangan kebutuhan dan tantangan pembangunan nasional, diperlukan keberpihakan politik ekonomi, yang memberi kesempatan dukungan dan pengembangan ekonomi rakyat, yang mencakup koperasi, usaha kecil dan menengah sebagai pilar utama pembangunan nasional tanpa mengabaikan peranan usaha besar dan Badan Usaha Milik Negara. Usaha besar dan Badan Usaha Milik Negara mempunyai hak untuk berusaha dan mengelola sumber daya alam, dengan cara yang sehat dan bermitra dengan pengusaha kecil, menengah dan koperasi. Pengelolaan dan pemanfaatan tanah dan sumber daya alam lainnya, harus dilaksanakan secara adil dengan menghilangkan segala bentuk penguasaan dan kepemilikan dalam rangka pengembangan kemampuan ekonomi usaha kecil, menengah dan koperasi serta masyarakat luas.

Kemudian dengan terbitnya Tap MPR No IX/MPR/2001 disusul dengan diterbitkannya Keppres No 34 Tahun 2003 maka semakin jelas arah kebijakan pembaharuan agraria dan pengelolaan sumber daya alam. Pe- 
merintah disini menegaskan tidak akan memarginalkan UUPA akan tetapi akan melakukan penyempurnaan. Untuk itu Badan Pertanahan Nasional ditugaskan untuk melakukan langkah-langkah percepatan, antara lain:

1) Mengajukan rancangan Undang Undang tentang Hak atas Tanah;

2) Menyusun peraturan perundang-undangan lainnya di bidang pertanahan.

Demikianlah garis kebijakan pembangunan Orde Reformasi yang berbeda benar dengan kebijakan rezim Orde Baru, tetapi sejalan dengan semangat yang terkandung dalam UUPA. Kebijakan Orde Reformasi lebih memihak pada rakyat banyak, khususnya usaha kecil, menengah dan koperasi. Dalam rangka mewujudkan tujuan kebijakannya maka telah dikeluarkan Keppres No 34 Tahun 2003 yang telah menugaskan kepada Badan Pertanahan Nasional untuk membuat rancangan penyempurnaan UUPA, undang-undang tentang hak milik dan peraturan perundang-undangan lainnya.

\section{Evaluasi Implementasi Kebijakan Pertanah-} an

Evaluasi dilakukan baik terhadap proses maupun hasil implementasi kebijakan. Penilaian terhadap proses kebijakan difokuskan pada tahapan perumusan kebijakan, terutama untuk melihat keterpaduan antar tahapan, serta sejauh mana program dan pelayanan masyarakat mengikuti garis kebijakan yang telah ditetapkan. Penilaian terhadap hasil dilakukan untuk melihat pengaruh atau dampak kebijakan, sejauh mana kebijakan mampu mengurangi atau mengatasi masalah. Berdasarkan evaluasi ini, dirumuskanlah kelebihan dan kekurangan kebijakan yang akan dijadikan masukan bagi penyempurnaan kebijakan berikutnya atau perumusan kebijakan yang baru. ${ }^{15}$

Pada hakekatnya evaluasi implementasi kebijakan yang berbentuk suatu undang-undang tergantung kepada beberapa hal yang antara lain:

a. Substansi undang-undang tersebut;

\footnotetext{
${ }^{15}$ Edi Suharto, 2005, Analisis kebijakan Publik, Bandung:
} Alfabeta b. Perkembangan masyarakat di mana undangundang tersebut diimplementasikan;

c. Strategi dan kebijakan pembangunan;

d. Keberadaan undang-undang tersebut dalam konteks peraturan perundangan lainnya;

e. Motivasi, dedikasi dan kemampuan aparat pelaksana undang-undang tersebut;

f. Image sosial dari undang-undang dan aparat pelaksananya. ${ }^{16}$

Upaya untuk mengevaluasi implementasi hukum pertanahan nasional yang berlandaskan pada UUPA merupakan sesuatu yang sulit mengingat keterbatasan waktu dan juga banyaknya faktor yang berpengaruh. Untuk itulah nanti hanya akan dievaluasi implementasi UUPA dari era rezim Orde Lama sampai dengan era rezim Orde Baru untuk dijadikan landasan kebijakan di era Reformasi dengan pisau analisis antara lain dengan memperhatikan akan adanya 6 hal yang harus diperhatikan dalam mengevaluasi implementasi kebijakan publik yang berbentuk suatu peraturan perundang-undangan.

Formulasi kebijakan pertanahan yang terkandung dalam UUPA di era rezim Orde Lama banyak mengalami pasang surut. UUPA telah dicoba diimplementasikan dengan orientasi tanah untuk rakyat penggarap (land to Tahune tiller). Jiwa kerakyatan yang begitu kental tentu saja sangat laku dijual untuk para petani yang melarat. Eksistensi UUPA telah menjadi dasar bagi penyediaan tanah untuk petani kusussnya petani penggarap dan buruh petani. Terbukti pada waktu itu banyak petani diantero tanah air yang melakukan okupasi atas tanah-tanah yang dijadikan obyek landreform. Aksi okupasi ini tentu saja disebabkan karena eng-gannya para tuan tanah atau penguasa tanah yang sangat luas untuk melepaskan tanahnya dijadikan obyek landreform.

Puncak dari peristiwa ini adalah terjadinya gejolak politik di tanah air yang pada akhirnya pada tahun 1965 tergulinglah rezim Orde Lama. Sejak saat itu program landreform otomatis terhenti, UUPA dibekukan. Terjadilah

\footnotetext{
${ }^{16}$ Lutfi Ibrahim Nasution, loc.cit, hlm. 77
} 
tragedi nasional yang dikenal sebagai $\mathrm{G} 30 \mathrm{~S}$ PKI.

Di era rezim Orde Baru, pengebirian UUPA mulai berlangsung. Hal ini tercermin dari orientasi dan praktek politik agraria yang ditopang oleh berbabagai produk peraturan perundang-undangan yang bersifat sektoral yang berkaitan dengan pengerukan kekayaan alam. Seperti misalnya, perundang-undangan yang mengatur sektor kehutanan, pertambangan, baik minyak maupun gas bumi, pengairan, perikanan dan sebagainya. Keseluruhan undangundang yang sektoral ini mengandung semangat dan isi yang arahnya untuk memfasilitasi para pemilik modal besar atau konglomerat dibanding memenuhi hak-hak rakyat seperti yang diamanatkan UUD 1945.

Akibat dari proses pengkhianatan yang berkepanjangan tentu saja posisi UUPA dengan sendirinya termarginalkan. Bahkan timbul kesan bahwa UUPA seakan-akan hanya mengatur soal administrasi pertanahan saja. Hal-hal lain yang bersangkut paut dengan bumi, air dan kekayaan alam diatur oleh peraturan perundang-undangan sektoral seperti tersebut di atas.

Jatuhnya rezim Orde Baru melahirkan era Reformasi. Sejumlah peluang perubahan khususnya di bidang kebijakan pertanahan telah terbuka. Kelahiran Tap MPR No IX Tahun 2001 telah membuka wacana untuk pembaharuan peratur-an perundang-undangan agraria. Pembaharuan ini mutlak harus dilakukan untuk memberikan dasar hukum bagi pelaksanaan pembaharuan agraria nasional. Untuk itu diperlukan semangat dari para penyelenggara negara untuk me-nyusun kebijakan agraria yang adil dalam mengelola sumber daya agraria secara ber-kelanjutan. Mandat untuk memperbarui ke-bijakan agraria secara tegas tertuang dalam Tap MPR No IX Tahun 2001 yang dalam pasal 6 nya menetapkan bahwa :

“Menugaskan DPR RI bersama Presiden RI untuk segera mengatur lebih lanjut pelaksanaan pembaruan agraria dan pengelolaan sumber daya alam serta mencabut, mengubah dan/atau mengganti semua undang-undang dan peraturan pelaksanaannya yang tidak sejalan dengan ketetapan ini”.
Berkaitan dengan hal ini maka pada 31 Mei 2003 Presiden Megawati Soekarnoputri telah mengeluarkan Keppres No 34 Tahun 2003 ten-tang Kebijakan Nasional Di Bidang Pertanahan yang memberikan mandat kepada Badan Pertanahan Nasional (BPN) untuk menyempur-nakan UUPA.

Menurut beberapa pakar ada banyak kelemahan yang perlu diperbarui, yang antara lain adalah:

a. Terlalu dominannya konsep hak menguasai negara atas tanah dan kekayaan alam. Pada kenyataannya konsep ini telah banyak dimanipulasi penguasa untuk menyingkirkan dan menegasikan hak-hak rakyat atas tanah dan kekayaan alam lainnya;

b. Pengakuan hak-hak masyarakat adat oleh UUPA sangat lemah. Sekalipun hak-hak ulayat berulang kali disebut dalam klausulnya, hampir semuanya memakai syarat yang justru melemahkan hak-hak adat itu sendiri;

c. UUPA menyempitkan pengaturan agraria hanya pada sektor pertanahan karena sebagian besar klausul dalam undang-undang ini hanya mengatur mengenai administrasi pertanahan. ${ }^{17}$

Berkaitan dengan mandat penyempurnaan UUPA berdasarkan Keppres No 34 Tahun 2003, Usep Setiawan mencatat sejumlah hal yang patut diperhatikan: ${ }^{18}$

a. Penyempurnaan UUPA mestilah bermakna menguatkan semangat kerakyatan yang terkandung di dalamnya. Penyempurnaan mestilah memperbaiki isi UUPAnya, bukannya menghapus atau menggantikannya dengan undang-undang lain yang semangat dan isinya sama sekali baru. Menyempurnakan berarti pula keharusan memperkuat orientasi pemenuhan hajat hidup rakyat, bukan sebaliknya.

b. Menyempurnakan UUPA mestilah dilakukan secara hati-hati, agar tidak terseret kepentingan globalisasi, kapitalisme yang hendak mengukuhkan kepentingan ekonomi politiknya di lapangan agraria. Oleh sebab itu,

\footnotetext{
${ }^{17}$ Usep Setiawan, Menemukan Pintu Masuk Untuk Keluar, Jurnal Analis Sosial, Vol.9, No 1 April 2005

${ }^{18}$ Usep Setiawan, op.cit, hlm. 75
} 
kandungan esensial penyempurnaan UUPA mestilah memastikan kebijakan politik agraria tetap berada di jalur populistik sebagaimana watak asli dari UUPA.

c. Penyempurnaan UUPA hendaknya meneguhkan posisinya sebagai payung bagi peraturan perundang-undangan agraria. UUPA yang diperbarui mestilah menjadi payung pelaksanaan pembaruan agraria yang berkeadilan. Pengaturan atas sektor kehutanan, perkebunan, pertambangan, perairan, pertainan, pesisir dan laut dan sebagainya mestilah mengacu secara konsekuen kepada UUPA.

d. Proses penyempurnaan UUPA hendaknya dijalankan secara demokratis dan partisipatif. Departemen dan lembaga negara lainnya yang terkait dengan agraria mesti terlibat aktif. Pakar dan organisasi non pemerintah (LSM) yang integritasnya teruji juga harus dilibatkan. Dan yang terpenting untuk diajak bicara adalah rakyat yang paling berkepentingan atas agraria, serikat petani, nelayan, masyarakat adat, dan rakyat kecil pada umumnya.

e. Penyempurnaan UUPA harus diikuti dengan penyiapan basis sosial bagi pelaksanaan pembaharuan agraria. Gerakan penyadaran, pendidikan politik dan pengorganisasian rakyat atau petani, serta sosialisasi gagasan kepada publik secara luas mutlak dilakukan untuk memastikan agenda pembaruan agraria menjadi agenda bersama bangsa. Dengan demikian konflik horisontal sesama anak bangsa akibat dijalankannya pembaruan agraria dapat dihindari sejak dini.

Dalam pada itu seiring dengan adanya reformasi yang menyeluruh dalam tatanan kehidupan bernegara yang diawali pada tahun 1997, maka menurut Maria SW Sumardjono ${ }^{19}$ timbul paradigma baru yang mestinya harus diakomodasi dalam menyusun kebijakan pertanahan yang baru. Penyelenggaraan pemerintahan yang sentralistis telah berubah ke arah desentralisasi (Undang Undang No 22 Tahun 1999 yang diubah dengan Undang Undang No 32 Tahun 2004). Peran serta masyarakat dalam pe-

\footnotetext{
${ }^{19}$ Maria SW Sumardjono, loc.cit, hlm. 201
}

ngelolaan sumber daya alam, penghormatan terhadap hak azasi manusia (HAM), transparansi, akuntabilitas publik dan efisiensi dalam pengelolaan sumber daya tanah merupakan isu-isu pokok good governance yang akan dijalankan oleh pemerintahan saat ini, dapat juga dijadikan landasan atau dijadikan sebagai pokok pikiran untuk menyususn kebijakan tanah yang baru. Upaya untuk melakukan penyesuaian UUPA dengan kecenderungan pemerintahan modern di era reformasi perlu dilakukan dengan hati-hati, transparan dengan pendekatan yang partisipatif. Hal ini dilakukan dengan melakukan revisi terhadap UUPA sekaligus mengkaji ulang peraturan yang bersangkut paut dengan sumber daya agraria sekaligus beserta peraturan pelaksana lainnya, tentunya kesemuanya ini harus dilandasi semangat dan tujuan negara tersebut dalam UUD 1945.

Hal yang tidak kalah menarik dalam masalah kebijakan pertanahan adalah tentang kelembagaan BPN. Hal ini sehubungan dengan pelaksanaan otonomi daerah menurut UU No 32 Tahun 2004 dimana telah timbul persoalan dengan terjadinya perbedaan penafsiran antara Pusat dengan daerah. Perbedaan ini sebenarnya telah muncul sejak keluarnya Keppres No 10 Tahun 2001 tentang kedudukan BPN dan Keppres No 34 Tahun 2003 tentang Kebijaksanaan Nasional di Bidang Pertanahan yang pada intinya menjelaskan bahwa urusan pertanahan masih menjadi ke-wenangan Pusat. Hal ini dipertegas lagi dengan Peraturan Presiden No 10 Tahun 2006.

Sengketa kewenangan ini kemudian di akhiri dengaan keluarnya Peraturan Pemerintah No 38 Tahun 2007 tentang Pembagian Urusan Pemerintahan Antara Pemerintah, Pemerintah an Daerah Provinsi dan Pemerintahan Daerah Kabupaten/Kota. Kewenangan dari Pusat meliputi hukum, kebijakan, pedoman mengenai pemberian hak-hak atas tanah, pendaftaran, landreform dalam bentuk undang-undang, PP maupun Keppres. Sementara itu kewenangan daerah cukup pada pelayanan masyarakat dan pelaksanaan kebijakan dalam bentuk perda ataupun keputusan kepala daerah. 
230 Jurnal Dinamika Hukum

Vol. 8 No. 3 September 2008

Hal tersebut di atas menurut Arie $\mathrm{S}$ Hutagalung adalah dalam rangka menjaga negara kesatuan maka kebebasan untuk mengatur dan mengurus bidang pertanahan akan tetap dilakukan dalam rangka kebijakan dasar dan pokok-pokok ketentuan hukum pertanahan nasional. Jadi, otonomi jelas tidak diartikan sebagai penyerahan pengaturan dan pengurusan segala masalah pertanahan sepenuhnya kepada daerah tetapi ada kewenangan yang bersifat pokok dan umum serta pembinaan Pusat terhadap pelaksanaan otonomi oleh daerah. ${ }^{20}$

Demikianlah sekelumit evaluasi implementasi kebijakan pertanahan nasional di mana esensi yang penting di sini adalah mempersiapkan potensi untuk menstimulasi ke arah perubahan kebijakan pembaruan agraria yang lebih berkeadilan dengan prinsip-prinsip desentralisasi, good governance dalam pengelolaan sumber daya tanah atau agraria atau ada juga yang menyebut sumber daya alam.

\section{Penutup}

Dari hasil pembahasan tersebut di atas maka dapat diambil kesimpulan sebagai berikut. Implementasi kebijakan publik di bidang pertanahan nasional dari berbagai rezim yang ada sangat determinan oleh faktor kepentingan politik. Oleh karena itu dalam evaluasi implementasi kebijakannya perlu diadakan pembaruan yang berkeadilan, kesejahteraan, dengan prinsip-prinsip desentralisasi, good governance dalam pengelolaan sumber daya tanah. Semua ini tentunya dalam rangka mencapai tujuan bersama yaitu mencapai masyarakat yang adil dan makmur berdasarkan Pancasila dan UUD 1945.

\section{Daftar Pustaka}

D, Riant Nugroho. 2005. Kebijakan Publik, Formulasi, Implementasi dan Evaluasi. Jakarta: Elex Media Komputindo;

Harsono, Budi. 2005. Menuju Penyempurnaan Hukum Tanah Nasional. Jakarta: Universitas Trisakti;

\footnotetext{
${ }^{20}$ Arie S Hutagalung, Markus Gunawan, 2007, Kewenangan Pemerintah di Bidang Pertanahan, Jakarta: Rajawali Pers
}

2005. Reformasi Hukum Tanah yang Berpihak kepada Rakyat, Makalah Seminar Nasional, Jakarta;

2007. Hukum Agraria Indonesia, Sejarah Pembentukan, Isi dan Pelaksanaannya, Jakarta: Jambatan;

Hutagalung, Arie S. Konsistensi dan Korelasi Antara UUD 1945 dan UUPA 1960. Jurnal Analis Sosial, Vol 29 No 21, April 2005;

-...-.-.-.-... 2007. Kewenangan Pemerintah di Bidang Pertanahan. Jakarta: Rajawali Pers;

Ibrahim, Lufti. 2005. Evaluasi Pelaksanaan UUPA, Program Masa Kini dan Mendatang. Makalah Seminar Nasional, BPN;

Nurcholis, Hanif. 2005. Teori dan Praktek Pemerintahan dan Otonomi Daerah. Jakarta: Grasindo;

Setiawan, Usep. 2005. Menemukan Pintu Masuk Untuk Keluar. Jurnal Analis Sosial, Vol.9, No 1 April 2005;

Suharto, Edi. 2005. Analisis Kebijakan Publik. Bandung : Alfabeta;

Wahab, Solichin Abdul. 2006, Analisis Kebijaksanaan, Dari Formulasi Ke Implementasi Kebijaksanaan Negara. Jakarta: Bumi Aksara;

Ya'kub, Achmad. Agenda Neo Liberal Masuk Melalui Kebjakan Agraria Di Indonesia. Jurnal Analis Sosial, Volume 29 No21, April 2005. 
Implementasi Kebijakan Pertanahan Nasional 231 